\title{
Left Ventricular Mass Index
}

National Cancer Institute

\section{Source}

National Cancer Institute. Left Ventricular Mass Index. NCI Thesaurus. Code C142243.

The left ventricular mass divided by the subject's body surface area. 